\title{
Economic Development and Participation of Women in Services Sector: Empirical Evidence from Egypt
}

\author{
Abeer Mohamed Ali Abd Elkhalek ${ }^{1}$ \\ ${ }^{1}$ Arab Academy for Science, Technology and Maritime Transport, College of Management \& Technology, Egypt \\ Correspondence: Abeer Mohamed Ali Abd Elkhalek, Associate Professor in Economics, Arab Academy for \\ Science, Technology and Maritime Transport, College of Management \& Technology, Egypt. E-mail: \\ abeer_abdelkhalek@yahoo.com
}

Received: December 17, 2018

Accepted: January 16, 2019

Online Published: January 20, 2019

doi:10.5539/ijef.v11n2p155

URL: https://doi.org/10.5539/ijef.v11n2p155

\begin{abstract}
The study has presented the lacking aspects concerning women and their roles in the economic development of the country through the assessment of their participation in service sectors through empirical evidence. The findings have shown a significant and positive impact of female illiteracy rate, GPP Growth rate, and industrial share on the female labour force participation. However, there is negative impact of female unemployment on female labour force participation on the female labour force participation. The results have also shown an insignificant and negative impact of urbanization share and industrial share. There is negative but significant impact of industrial share on the female force labour participation in Egypt. The results emphasize on the participation and economic development of female population in the service sector.
\end{abstract}

Keywords: economic development, education, service sectors, women, participation, Egypt

\section{Introduction}

Job creation has emerged as a major constraint of the employment sector in Egypt. Efforts have been made to identify the primary cause of lack of jobs and prevailing unemployment rates in the state. Development of effective economic opportunities among youth of Egypt will assist to preserve the foundation of a country in the centre of demographic evolution (Murata, 2014). In this aspect, the demographic realties of region are identified as the key contributor (Waterbury, 2014). Significant population growth in the state of Egypt has been observed over the past few years. The population growth resulting in increasing job seekers has significantly affected the competition and selection criteria. However, the employment trends in the market have portrayed another reality that displays an increase in the labour demand and a decrease in supply (Swallow Meinzen-Dick, \& Van Noordwijk, 2016). The disparities in the job market have been owed to the elements of low education level, improper professional training, and skill development. Thus, job seekers failed to qualify for the employment due to lack of professional characteristics, despite of the sufficient number of jobs available. The revelation has emphasized on the approach of current economic situation of Egypt to develop strategies that may provide required boost to the industry (Emara, Plotkin, \& Stein, 2013).

Women are considered to be an unrecognized and unutilized human reserve. Lowest Female Labour Force Participation has been observed in Jordan, Egypt, Tunisia, and Morocco (Spierings \& Smits, 2007). Women labour force participation is directly proportional to the economic development. Greater variations in the labour force participation by women as compared to men are being witnessed in many developing countries. Certain variations include economic factors as well as social factors, which involves education, social norms, and economic growth (Verick, 2014).

The participation of women in labour force in Middle East and North African region (MENA) is observed to be low in the terms of international standards (Karshenas, Moghadam, \& Chamlou, 2016). However, MENA has rapidly increased in the progress of female education, but this increase has not translated into the increased female labour work force. The female participation in the employment trend has moved slowly upwards from $22 \%$ to the $28 \%$ in MENA as compared to the other region. A total of $45 \%$ of the urban families are being indicated as a barrier for the girls to participate in the employment sector in the Middle East (Morikawa, 2015). However, women in Saudi Arabia are broadly increasing the employment rate in the education sector. The female lecturers are increased with a number of 4700 in 2003-2004 to 19,600 in 2008-2009. Therefore, women should be 
provided with good career opportunities in the higher education leadership, as they have a good ratio of higher education faculty and the education sector is always gender biased (Alsubaie \& Jones, 2017).

However, the economic participation of women in MENA is observed to be low across the world, with the percentage of $25.2 \%$ of the women aged from 15 and above, participating in the labour workforce. The percentage is approximately 50, in contrast with other regions like Europe, Eastern Asia, Pacific, Sub-Saharan Africa and Central Asia (Shalaby, 2014). The retirement age is also considered to be a barrier for women in MENA for less labour workforce. The retirement age among women seems to be low as compared to the men; therefore, there is reduction in career expectations of women and the pension rate (Momani, 2016). Moreover, employment rate among the married women seemed to be as low as $27 \%$ as compared to the unmarried women in Egypt i.e. (18\% vs $25 \%$ ), Tunisia $46 \%$ lower i.e. (18\% vs $34 \%$ ) and $57 \%$ lower Jordan i.e. (12\% vs. $28 \%$ ) (Assad, Krafft \& Selwaness, 2017). The rate of unemployment in MENA is observed to be very high specifically among women with a university degree. The likelihood of being unemployed seems to be $20-400 \%$ higher among the participants of labour force who possessed tertiary education. The unemployment rate is observed to be greater as compared to the women with primary and secondary education, due to the higher economic activity rate among the college women (Karshenas, Moghadam, \& Chamlou, 2016).

Half of the region in Egypt comprise of women, who suffer from major challenges, particularly at the end of employment level. According to the Egyptian Labour force, there is increase in the rate of unemployed females from $23.7 \%$ in 2006 to $27.6 \%$ in 2012 . This ratio has been presented despite of the fact that they merely represent $23 \%$ of the labour force. Furthermore, participation of Egyptian women labour force is between 20-25\% during 2000s, which is considered very low as compared to the global percentage of 52\% (Assaad and Krafft, 2013). Moreover, according to Labour Force Sample Survey (2005), majority of the job seekers; particularly women, leave the employment ground before hitting the age mark of 30 years. Ultimately, the unemployment rate in women appears to be three times greater as compared to their male counterparts. Female participation in governmental sector in Egypt is approximately 30\%. Women were found to prefer the government jobs due to its flexibility, social security, and several other benefits, including maternity leave, medical aid, and better working conditions, which are seldom offered by the private sectors. Therefore, the present study has addressed the empirical evidence from Egypt to elabourate the economic development of the country and lack of participation of women in the service sector. An alarming need of women's training programs has been provoked by the study to enhance the women participation in social services of the country.

The study has contributed to present the lacking aspects of the country concerning women and their roles in the economic development. The knowledge and gaps of necessary aspects are required to be prevailed among women to reduce unemployment rate and enhance economic development of the country. The study has highlighted that half of the region of Egypt is comprised of women, so their participation in the economic as well as social sector will eventually enhance the development of the country. The study has aimed to evaluate the extent of women participation in the economic development of Egypt and how the employment and education among women can be popularized. The contribution emphasizes the participation and economic development of female population in the service sector. It also endorses to promote programs that might encourage them to participate in the activities concerning the economic services and development.

\subsection{Research Questions}

Question 1: Do women participate efficiently in the economic development of the country?

Question 2: Are there any training programs for the Egyptian women that may motivate them to participate in the service sectors?

Question 3: What are the roles played by women for the economic development of the country?

\section{Literature Review}

In recent years, $2.8 \%$ of annual rise has been observed in the labour force of Egypt. Young individuals between 15 to 29 years have been increasingly contacting the employment sector. The growth rate for youth has been estimated about 3\% per annum. Furthermore, it has been observed that the labour force in Egypt is primarily dominated by men. However, the rate i.e. dominated by men seemed to be $73 \%$ whereas, women are only participated with the rate of $23 \%$ (Fadl, 2015). The suppressed figures for female participation in the employment sector are mainly attributed to the conservative cultural norms of the region and the patriarchal approach of the society (Bhorat et al., 2016). However, greater participation in the education since the early age provides greater and better opportunities for women in terms of economy. This will increase an overall human capital level and labour productivity (Adema, 2014). 
Several political parties in Egypt such as Muslim Brotherhood place restrictions on women and do not allow them to secure leadership positions under their rule (Bary, 2016). It results in demotivating the women workers performing their duties in various companies. Considering this situation, there is a need for starting a public awareness campaign by the government, which mobilizes the public to raise their voice on national and international forums. It can play a critical role in changing the perceptions and making relevant adjustments in current processes or policy frameworks to help women get equal representation in service sector (Ghafar, 2016).

Low representation of women in service sector has been an area of concern for the Egyptian authorities as it can have a negative impact on the economic development of the country. The gender in the service sector and labour force involvement are high in Egypt. Women's involvement in the service sector has dropped significantly during the period of 2016-2012, despite the efforts of the government to increase the literacy rate among female population. The women involve themselves in work activities that can be started with limited resources so that they are able to support their families (Tawakol, 2017). According to experts, it is necessary to identify the main reasons, which decrease the participation of women in labour force. The involvement of women in labour force contributes towards economic stability in the region. However, there are few barriers faced by women in the Middle East, which has a negative impact on women participation (Tsani et al., 2015). Policies which are adopted for removing entry barriers encourage the women to enter into labour force and service sector. Relevant authority makers need to understand different parameters associated with the market in formulating policies so that women are able to participate in service sector (Winkler, 2016).

Social and domestic transformations have been suggested by various entities for bringing improvement in the context of female participation. Such transformation will lead to the positive changes in the corporate practices within their own context. This will also enlarge the female talent pool (Adema et al., 2014). The efficiency level of labour forces is declining in Egypt due to less opportunities provided to the women (Hendy, 2015). While, the demographic factors are also increasing the burden on the domain (Mulligan, Keulertz, \& McKee, 2017). Geographical composition has roughly estimated that about $40 \%$ to $60 \%$ individuals living in urban areas form the country's labour force. While, major number is contributing to the population growth from the rural regions (International Labour Organization, 2016).

The nature of unemployment in Egypt is marked with a market insertion; it occurs primarily while approaching for the first job. Market insertion mainly prefers educated individuals rather than the unskilled and illiterate workers. The Labour Force Sample Survey (2005) depicted a rise in the number of unemployed individuals, showing that $92 \%$ of the affected people had belonged to the age of under 30 years. The rate of evacuation presented by women is considered as a great challenge that is being faced by the economic field (Doloi et al., 2012). It has been explored that women tend to leave the employment sector by the age of 30 years. Furthermore, social values are linked with the employment rate, which ultimately affect the human development (Fischer, 2014). Surprisingly, unemployment rate among educated women has been observed greater as compared to the unskilled professionals (Hendy, 2015).

Nazier (2016) identified the factors that determine the Egyptian women's decision to take part in the labour force using the "Egypt Labour Market Panel Survey" (ELMPS). The findings of this study revealed that there is variation in the factors affecting women's decision to work in the labour force. The decision related to participating is not the same; whereas, community element plays a significant role in the decision related to participating in the labour force. However, community context does not play an important determinant in the status of women leading to employment, if they get involved in the labour force. The youth belong to Middle East suffer high unemployment. The rate of unemployment is much greater than the males, despite of the fact that some of the countries consist of 50\% women engaged in universities and colleges than males. Mirzaie (2014) examined the factors involved in female unemployment in Turkey, Egypt and Iran. The study revealed that the increase of rate per capita income decreases the labour force participation (LFP) in Iran and Turkey whereas, it is vice versa in Egypt. In Iran, the increase in age is the factor that reduces the rate of unemployment among women but in Turkey inverse effects of labour force participation (LFP) were witnessed. It is also said that the Iranian government is spending much money in the programs promoting women employment.

Lechman and Kaur (2015) studied the relationship between women labour force and growth in economy among 162 countries of the world. The study hypothesized that the results would give a U-shaped linkage between economic growth and women labour force participation. The study was analysed based on two different factors such as: data collection from 162 countries and the relationship between four groups (low income group, lower middle-income group, upper middle-income group and high-income group). The data was collected on women labour force participation and per capita income to identify the relationship between these groups. The findings supported U-shaped linkage between women labour force participation and growth in economy. However, the 
U-shaped relationship did not support the feminization in the low-income group or countries. Kabir (2016) examined the concept of empowerment in terms of gender and development as well as the concerns related to women economic empowerment. Additionally, the study identified the concept of empowerment through the theoretical approaches of gender inequity and labour market. The study demonstrated some of the literature based on gender inequalities and labour market to reveal the barriers and hurdles faced by women in the economic progress. These factors not only showed that educating women is important but also intimated to provide further opportunities to the women in the labour and employment sector. The study suggested that the office work has a great impact on the development of women; however, the domestic employment also has positive influence on women live.

Besamusca et al. (2015) investigated the eleven age groups of women in terms of influence of families, education, economic condition, and concept of gender on the labour force participation among 117 countries of the world. The study found out that the participation ratio of young and old female group is partially explained by the economic development and the sector sizes. Whereas, the researcher needs to study families and gender ideologies to identify the rate of labour force participation ratio among women with the age of 25 to 55 years. The study found out that the women of 25 to 55 years old are more interested in the participation, when paid leaves or maternity leaves are offered to them. Researchers and policy makers in Egypt noted that labour forces have displayed gender discrimination and other forms of socio-economic inequality concerning the class, background, competition, and ethnicity of the individuals (Hendy, 2015). Thus, the labour group never earned the recognition of a homogenous community. It was identified that a mainstream intervention of gender equity is needed in the developmental policy to conceptualize the empowerment of women (The World Bank, 2017). With the increase in world trade services, global firms have majorly focused to provide better occupations, improved place to work, and flexible working conditions for the women. The social relation involved with the pervasive income gap and conservative gender ideologies are not surprising to relate with the suppression of women in the field. It is high time now to provide women with a key role to participate for the global economy for the progress of the nation as well as the society (Omair, 2011).

\section{Theoretical Framework and Hypothesis Development}

The hypothesis based on U-shaped theory was proposed by Goldin (1995). Accordingly, women are being served as an unpaid worker in the family owned business at the lower GDP level per capita. With the economic development, the options from agricultural and manufacturing sectors are being created for women so that they can work as paid workers. However, they still face social barriers for joining these sectors. More chances are present for women in the economic development in terms of education sector; therefore, women have started achieving higher levels in such sectors in the form of white collar jobs. This led to enhanced female participation in the labour force (Husain, 2016). Moreover, Goldin (1995) has revealed a declined part of U-shaped i.e. by the income effect. The goods based on household seemed to be less profitable as compared to the factory based goods. Similarly, the demand of the wage labour was decreased due to the emergence of advanced technology in the agricultural sector. Social, religious, and cultural barriers are also observed in this regard. However, the rising part of $\mathrm{U}$ is being explained by the substitution effect. According to the substitution effect, the income given to the women leads to the wider access to the education sector and modern technology. They are also offered a good position in the service sector as a highly paid worker.

The substitution effect is more efficient than the income effect that allows women to be a part of labour force. However, the income effect seemed to be dominating in the initial phase of the economic development. In line with Goldin (1995), U-shape has indicated a relationship between the growing economic development and women education. At the initial stage of economic development, the development in male education as compared to female dominates the substitution effect. However, substitution effect becomes stronger than the income effect among women with greater and broader access to education (Husain, 2016). Tinsel (2001) has asserted that urbanization and unemployment affected the economic growth and female labour force participation. However, the impact of unemployment can be positive on FLPR only if the discouraged worker effect is being dominated by the added worker effect. Due to the added worker effect, the rate of male unemployment is high which result in the responsibility taken by women to become a bread earner for the family. Moreover, if the discouraged worker effect starts dominating the added worker effect then the impact of education on FLPR can be negative. The discouraged worker effect serves as a psychological and economical cost for searching the job that is high that might hinder the women to be a part of the labour market.

$\mathrm{H}_{0}$ : Women participation in service sectors significantly enhance the economic development of the country.

$\mathrm{H}_{1}$ : Women participation in service sectors does not enhance the economic development of the country. 


\section{Material and Methods}

The labour force participation of a women is the collaboration of a mutual decision-making process of her household. A panel data has been collected for the 27 governorates of Egypt from 2013-2017. The study has included several variables that influence female labour force participation rate. These variables include the level of education of women, female illiteracy rate, female high school enrolment rate, and female population, female labour force participation rate, per capita gross provincial product, female unemployment rate, urbanization rate, and industrial employment share. The secondary data for these variables were collected from the World Bank database, Euromonitor Website, and official statistics website of Egypt.

The ordinary least squares (OLS) method have been used to estimate the female labour force participation. The cultural differences were captured through dummy variables that might impact the labour force participation of women. The year 2013 was considered as a base year in the estimation model. The OLS estimation is a sort of fixed-effects estimation with the adoption of the regional dummy and time dummy variables. Table 1 has presented the means and standard deviations of the constructs used in this study. The mean and SD values reported for female labour force participation $(\%)$ were $42.08 \pm 9.11 \%$. Similarly, the mean and SD values reported for per capita gross provincial product were $2.11 \pm 1.16 \%$. The mean and SD values for urbanization rate were reported as $39.13 \pm 11.77 \%$.

Table 1. Descriptive statistics

\begin{tabular}{lcc}
\hline Variable & Mean & Standard deviation \\
\hline Female labour force participation rate (\%) & 42.08 & 9.11 \\
Per capita gross provincial product & 2.11 & 1.16 \\
Female illiteracy rate (\%) & 29.18 & 11.78 \\
Female unemployment rate (\%) & 1.11 & 0.89 \\
Urbanization rate (\%) & 39.13 & 11.77 \\
Industrial employment share (\%) & 9.11 & 5.23 \\
\hline
\end{tabular}

\section{Results and Discussion}

The results for dummy variables and model statistics have been shown in Table 2 and 3. The findings have shown a positive but insignificant dummy time period base (2013) in model 1 as well as in model 2. Moreover, a significant but negative dummy time period base (2008) in model 1; whereas, positive but insignificant dummy time period base (2008) was shown in model 2. The results have shown an $84 \%$ variation in both models for the variables used in this model. This shows a positive and significant chances of indicators on the female labour force participation. This result in improved employment rate and women will be able to actively participate in the service sector. Improvement in the policy reforms of public and private sector organizations can be made with the collaborative effort of the government so that the participation rate of women is increased.

Table 2. Time dummy variables

\begin{tabular}{lcc}
\hline Time dummy variables & Model 1 & Model 2 \\
\hline Dummy 2008 & $-0.651(1.51)$ & $0.520(1.21$ \\
Dummy 2013 & $1.711(2.31)$ & $2.714(5.01)$ \\
\hline
\end{tabular}

Table 3. Model statistics

\begin{tabular}{lcc}
\hline & Model 1 & Model 2 \\
\hline Constant & $449.72(4.11)$ & $520.27(4.78)$ \\
R-Squared & 0.752 & 0.941 \\
Adj. R-Squared & 0.841 & 0.847 \\
F-Statistic & 215.1 & 214.0 \\
No. of observations & 195 & 195 \\
\hline
\end{tabular}

Table 4 has shown the OLS estimation results with female labour force participation rate from 2013-2017. The findings have shown a significant and positive impact of female illiteracy rate, GPP Growth rate, and industrial share on the female labour force participation rate (Model 1). Majority of the women in urban areas, with higher 
education prefer to stay at home and take care of their families. Whereas, the women in rural areas, with lower education, are expected to work as labour in the fields. The societal notion of biasedness had created a big gap between the employment sector and the economic development in Egypt (Hyde, 2013). Improvement in literacy rate among women contribute towards influencing the organizations to introduce workplace reforms, which has resulted in improving the retention rate of women (Ibrahim, 2013). The inconsistent organizational policies is the major contributing factor that causes low involvement of women. There is a need for making relevant changes in the current processes so that women are able to participate actively in the economic growth of Egypt.

Table 4. OLS estimation results with female labour force participation rate, Egypt (2013-2017)

\begin{tabular}{lcc}
\hline & Model 1 & Model 2 \\
\hline Female illiteracy rate & $0.201(1.13)$ & $-0.053(1.69)$ \\
Female unemployment & $-1.156(1.19)$ & $-0.650(1.68)$ \\
Log per capita GPP & $-40.566(2.29)$ & $-65.01(2.86)$ \\
GPP Growth rate & $12.564(0.91)$ & $16.604(1.15)$ \\
Urban share & $-0.196(7.16)$ & $-0.255(6.06)$ \\
Industrial share & $-0.228(2.02)$ & $-0.290(1.39)$ \\
\hline
\end{tabular}

The increasing level of educational activities among women has presented a strong association between the education and participation of females in the labour force. The outcomes present the expectation of a rise in number of females in the labour force yet the data keeps on displaying a fall down. It suggests a decrease in opportunity structure for women in the labour market. This has been mainly attributed to the public-sector employment, upon which women seldom rely due to the weak structure of facilities. Decline in the participation rate of women have continued to mount in the period of 2006-2012, where even males were deprived of their rights due to lesser alternatives (Hebisha \& Fathi, 2014).

Educational activities have been identified as significant elements concerning the working population in the period of 2006-2012. The increasing educational attainment and rising share of the university students have been distinguished primarily. The rate of participation among females has been increased significantly, who have had a high school degree. The element delivered a need among labour supply and pressures on the labour market to accommodate the educated competitors. The female market force has considerably compressed and presented the rate of $4.2 \%$ per annum, in the years 2006-2012, after growing 3.1\% per annum over the period of 1998-2006.

In contrast, findings have shown a significant but negative impact of female unemployment on female labour force participation (Model 1). The unemployment rate among women in Egypt is observed to increase with the passing decades. It is presumed that the incidence will grow more with time, if precautionary measures are not implemented. Major contributors of the deteriorating rates of female participation in service sector are recognized as the social and domestic approach. The factors mainly include the dual roles of women in juggling between the domestic chores and professional responsibilities. Women are considered less stable for a professional role, due to extended maternal and conjugal accountabilities. The conservative approach further contributes to the gender discrimination at service sectors and biasedness of society that expresses reluctance in hiring a woman for a vital job. Participation of Women in the Economy and Reform (POWER) activities are working to support and empower women in the fields (Dighe \& Reddi, 2015). However, the opportunities and employment quality for the better jobs seemed to be unequal for men and women in the developing countries. Women in these countries tend to earn less than men as they do not get chance to work in the productive jobs; although, there is parity in the labour force participation by both men and women. They are also unpaid workers for their family business and are engaged in other vulnerable work. The segregation of employment by the gender is observed in all the countries due to this the improvement in economic empowerment of women cannot be possible, resulting in subordinate position of women (Verick, 2014). Labour force in Egypt is mainly dominated by males that is representing approximately $4 / 5^{\text {th }}$ of population at workplace. Low involvement of women at workplace, especially in the service sector is due to organizational policies and cultural norms. The policies adopted by organizations force the women workers to quit their jobs within one year. However, recent trends and survey results indicate that the involvement of women in labour force is increasing as a result of improved government policies.

The results have also shown an insignificant and negative impact of urbanization share and industrial share (Model 1) on the female labour force participation rate. Lack of organizational support for women has encouraged women to develop their own authorities in the time of need. Therefore, a rise has been noticed 
associated with the empowerment of women in developing their own authorities and decisions with decreasing rate of employment for women. Women are not provided with proper guidance and assistance to deal with their own business set ups or to start their own organizations. Thus, non-governmental organizations (NGOs) that are dedicated towards empowerment must consider the efforts of such women and assist them by providing strength and eradicating gender disparities (Sorbera, 2013). Women in Egypt have been suppressed by cultural norms, gender disparity, and early marriages, decreased education, and declined authority for decision making (Shah, 2013). The percentage of women participation at workplace has observed a significant shift. In the year 1988 illiteracy rate was 81 percent among female population working in corporations and 47 percent in 2006 . The number of female graduates in the rural areas has increased to 22 percent during the period of 1988 to 2006. The major shifts in the women literacy rate and women educational institutes has positive influence on the participation of women in labour force. The involvement of females increases as the number of technical women schools and educational institutes increase in the region (Assaad, 2009). Assaad (2009) revealed that increase in the women educational institutions and literacy rate has a positive and significant impact on women participation in service sector and labour force.

The study has shown a negative but significant impact of industrial share on the female force labour participation in Egypt. Egypt has delivered a continually developing trend with the composition of its educational approach and working population. In general, it can be expected to have a positive impact on the growth of labour force as women have been encouragingly attaining secondary education level. However, the female participation in the service sectors has not raised with the educational development. Opportunities for women participating in the employment sector have worsened over time due to the organizational and societal restrictions within the country. The decline has been further compounded by the delay in the growth of employment opportunities in the public and private sectors. There is an increasing unemployment rate in the country, indicating the extended degree of individuals searching for the work. It is high time for the sectors to deploy updated policies and implementations to fulfil the need of organizations that can later serve the state economy.

The effects of women's role on economy and the associated factors are worse in Egypt. Generally, the understanding of women's power and participation was observed to have no value to the working capabilities (Diamond-Smith, Bishai, \& Gibaly, 2015). These barriers and challenges are needed to be focused and action-oriented projects for women empowerment are needed to be formulated for raising the economic reform of the country. It has been evaluated that raising the education level in younger population, especially in girls may significantly help in developing better economic scenario. Under the market definitions, decrease in workforce is relatively larger in the rural areas as compared to the urban areas. The decline in male market labour force by $2.7 \%$ per annum has been consistent with the decline in the youth population. In the year 1998-2006, growth of female labour force appeared relatively slower than the male labour force, suggesting that the female labour participation rates were falling persistently. Both females and males have displayed diverse stages of unemployment. Understanding the women participation and economic growth components in Egypt holds significance as it allows policy makers to identify the vulnerabilities that exist in the system. Government institutions can make necessary changes in the processes, based on multiple market and economic parameters.

\section{Conclusion}

The present study has discussed the changes in the educational and age composition. There is a need of training programs in Egypt to motivate women for participating in economic development of the country. The results of OLS have illustrated that women participation in service sectors can significantly enhance the economic development. In addition, econometric models have also illustrated that there is large variation of explanatory variables concerning the role of women. Moreover, educational activities among women must be prevailed to encourage young females for contributing to the developmental activities. Decrease in such activities has been found prominent through the analysis of previously conducted studies on the motive of economic development in Egypt. Future studies must focus on the educational activities conducted in different schools and colleges or any other educational institute in the country for more comprehensive analysis. The approach might help the researchers to evaluate the training activities and enhance the motivational level of women in future.

The participation of women in the labour force can be influenced by certain key policies either directly or indirectly by increasing women's physical mobility. However, the interventions taken in this area should be thoroughly tested as several policies are not being tested yet. The best policies and programs should be designed by the government and a set of studies should be conducted to spread the benefits and most of women engagement in the labour work force for enhancing the women labour force. Moreover, the policies focusing on the increased education level should be designed due to a strong association between female economic activity rate and education level. Higher education will also enhance the opportunities for women to do a decent job as 
well. However, the policies for the informal economic activities are required to enhance the working conditions and income of working women.

\section{Acknowledgements}

The author is very thankful to all the associated personnel in any reference that contributed in/for the purpose of this research.

\section{References}

Adema, W., Ali, N., Frey, V., Kim, H., Lunati, M., Piacentini, M., \& Queisser, M. (2014). Enhancing women's economic empowerment through entrepreneurship and business leadership in OECD countries. Background Report of OECD to China Development Research Project.

Alsubaie, A., \& Jones, K. (2017). An Overview of the Current State of Women's Leadership in Higher Education in Saudi Arabia and a Proposal for Future Research Directions. Administrative Sciences, 7(4), 36. https://doi.org/10.3390/admsci7040036

Assaad, R., Krafft, C., \& Selwaness, I. (2017). The Impact of Early Marriage on Women's Employment in the Middle East and North Africa (No. 66). GLO Discussion Paper.

Assaad, R. (2009). Labour supply, employment and unemployment in the Egyptian economy, 1988-2006. The Egyptian Labour Market Revisited. https://doi.org/10.5743/cairo/9789774162480.003.0001

Barsoum, G. (2016). The public sector as the employer of choice among youth in Egypt: The relevance of public service motivation theory. International Journal of Public Administration. https://doi.org/10.1080/01900692.2015.1004082

Bary, I. (2016). Women's political partcipation in muslim brotherhood between the hammer of ambiguity and the anvil of inclusion-moderation: The case of Egypt and Tunisia (Master's thesis, Norwegian University of Life Sciences, Ås).

Besamusca, J., Kea, T., Maarten, K., \& Stephanie, S. (2015). Working women worldwide. Age effects in female labour force participation in 117 countries. World Development. https://doi.org/10.1016/j.worlddev.2015.04.015

Bhorat, H., Steenkamp, F., Rooney, C., Kachingwe, N., \& Lees, A. (2016). Understanding and characterizing the services sector in South Africa: An overview (No. 2016/157). WIDER Working Paper.

Diamond-Smith, N., David, B., \& Omaima, El G. (2015). Inter-generational co-residence and women's work and leisure time in Egypt. Demographic Research. https://doi.org/10.4054/DemRes.2015.32015. 3.31

Dighe, A., \& Usha, V. R. (2015). Women's Literacy And Information And Communication Technologies: Lessons That Experience Has Taught Us. International Women online Journal of Distance Education.

Doloi, H., Anil Sawhney, K. C. I., \& Sameer, R. (2012). Analysing factors affecting delays in Indian construction projects. International Journal of Project Management. https://doi.org/10.1016/j.ijproman.2011.10.004

Emara, N., David, P., \& Alyssa, S. (2013). Foreign aid and growth in Egypt: The role of economic policy.

Fadl, N. (2015). The labour market in Egypt. Retrieved from http://www.enid.org.eg/Uploads/PDF/PB33_labour_market_eg.pdf

Fischer, A. M. (2014). The Social Value of Employment and the Redistributive Imperative of Development.

Ghafar, A. A. (2016). Educated but unemployed: The challenge facing Egypt's youth. Brookings Doha Center, $1-16$.

Hebisha, H., \& Fathi, M. (2014). Small and medium scale aquaculture value chain development in Egypt: Situation analysis and trends.

Hendy, R. (2015). Women's participation in the Egyptian labour market: 1998-2012. The Egyptian Labour Market in an Era of Revolution. https://doi.org/10.1093/acprof:oso/9780198737254.003.0008

Husain, H. (2016). Economic Development, Women Empowerment and U Shaped Labour Force Function: Time Series Evidence for Bangladesh. Asian Economic and Financial Review, 6(12), 719. https://doi.org/10.18488/journal.aefr/2016.6.12/102.12.719.728

Hyde, G. D. M. (2013). Education in modern Egypt (RLE Egypt): Ideals and realities. Routledge. https://doi.org/10.4324/9780203070390

Ibrahim, M. (2013). The determinants of private sector demand for employment in Egypt: 1990-2007. 
Internation Labour Organization. (2016). India Labour Market Update. Retrieved from https://www.ilo.org/wcmsp5/groups/public/---asia/---ro-bangkok/---sro-new_delhi/documents/publication/w cms_496510.pdf

Kabir, N. (2016). Women's economic empowerment and inclusive growth: Labour markets and enterprise development. School of Oriental and African Studies.

Karshenas, M., Moghadam, V. M., \& Chamlou, N. (2016). Women, Work, and Welfare in the Middle East and North Africa: Introduction and Overview. In Women, work and welfare in the Middle East and North Africa: The role of socio-demographics, entrepreneurship and public policies (pp. 1-30).

Krafft, C., \& Ragui, A. (2016). The Evolution of Labour Supply and Unemployment in the Egyptian Economy: 1988-2012. The Egyptian Labour Market in an Era of Revolution. https://doi.org/10.1093/acprof:oso/9780198737254.003.0001

Krafft, C. (2013). The structure and evolution of employment in egypt: 1998-2012.

Lechman, E., \& Harleen, K. (2015). Economic growth and female labour force participation-verifying the U-feminization hypothesis. New evidence for 162 countries over the period 1990-2012.

Mirzaie, I. A. (n. d.). Females' Labour Force Participation and Job Opportunities in the Middle East. Department of Economics.

Momani, B. (2016). Equality and the economy: Why the Arab world should employ more women.

Morikawa, Y. (2015). The Opportunities and Challenges for Female Labour Force Participation in Morocco. Global Economy \& Development Working Paper, 86.

Mostafa, M. M. (2003). Attitudes towards women who work in Egypt. Women in Management Review. https://doi.org/10.1108/09649420310485096

Mulligan, M., Keulertz, M., \& McKee, M. (2017). Environmental Factors in the MENA Region: A Swot Analysis. $C I D O B$.

Murata, A. (2014). Designing youth employment policies in Egypt. Brookings Global Working Paper Series.

Nazier, H., \& Racha, R. (2016). Women's participation in labour market in Egypt: Constraints and opportunities.

Omair, K. (2011). Women's managerial careers in the context of the United Arab Emirates. Jyväskylä Studies in Business and Economics.

Shah, N. D. (2013). Effect Of Urbanization And Level Of Education On Women's Age At Marriage In Yemen, 1997.

Shalaby, M. (2014). The Paradox of Female Economic Participation in the Middle East and North Africa. Issue Brief.

Sorbera, L. (2013). Early Reflections of an Historian on Feminism in Egypt in Time of Revolution. Genesis.

Spierings, N., \& Jeroen, S. (2007). Women's labour market participation in Egypt, Jordan, Morocco, Syria \& Tunisia: A three-level analysis. In IZA/World Bank Conference Employment and Development.

Swallow, B., Ruth, S. Meinzen-Dick, \& Meine, V. N. (2005). Localizing demand and supply of environmental services: Interactions with property rights, collective action and the welfare of the poor.

Tam, H. (2011). U-shaped female labour participation with economic development: Some panel data evidence. Economics Letters, 110(2), 140-142. https://doi.org/10.1016/j.econlet.2010.11.003

Tansel, A. (2002). Economic development and female labour force participation in Turkey: Time-series evidence and cross-section estimates.

Tawakol, A. (2017). Women and Work in Egypt: The Effect of the Election of the Muslim Brotherhood on Female Labour Force Participation.

The World Bank. (2017). Progress Towards Gender Equality in the Middle East and North Africa Region. Retrieved from http://documents.worldbank.org/curated/en/801561511848725797/pdf/121679-WP-27-11-2017-15-23-11MNAProgressTowardsGenderEqualityFINALSept.pdf

Tsani, S., Leonidas, P., Costas, F., Ioannis, C., \& Pantelis, C. (2015). Female labour force participation and economic development. https://doi.org/10.1007/978-3-319-11122-3_19 
Verick, S. (2014). Female labour force participation in developing countries. IZA World of Labour. https://doi.org/10.15185/izawol.87

Waterbury, J. (2014). The Egypt of Nasser and Sadat: The political economy of two regimes. Princeton University Press. https://doi.org/10.1515/9781400857357

Winkler, A. (2016). Women's labour force participation. Family-friendly policies increase women's labour force participation, benefiting them, their families, and society at large. Retrieved from https://wol.iza.org/uploads/articles/289/pdfs/womens-labour-force-participation.pdf

\section{Copyrights}

Copyright for this article is retained by the author(s), with first publication rights granted to the journal.

This is an open-access article distributed under the terms and conditions of the Creative Commons Attribution license (http://creativecommons.org/licenses/by/4.0/). 